\title{
The effect of natriuretic peptides and bradykinin on development of brain oedema after ischemic stroke
}

\author{
Marina Dobrivojević ${ }^{1,2}$, Katarina Špiranec ${ }^{2,3}$, Dunja Gorup ${ }^{1,2}$, Igor Erjavec ${ }^{4}$, Srećko Gajović ${ }^{1,2}$, Aleksandra Sinđić $2,5^{*}$ \\ From 7th International Conference on cGMP Generators, Effectors and Therapeutic Implications \\ Trier, Germany. 19-21 June 2015
}

\section{Background}

Ischemic stroke is characterized by a rapid loss of brain function due to disturbance in blood supply to a part of the brain. Due to fixed intracranial space, any increase in intracranial fluid volume, or progressive brain oedema formation, contributes to further deterioration of the already impaired brain function. Bradykinin (BK), which levels increase during ischemic stroke, promotes bloodbrain barrier permeability and raises intracranial capillary blood pressure, leading to brain oedema formation. Furthermore, BK induces glutamate release from neurons and astrocytes via activation of BK receptor type 2 . suggesting involvement of BK in glutamate neurotoxicity. It has been recently shown that humans without functional natriuretic peptides (NPs) suffer from massive stokes $[1,2]$.

NPs can reduce brain oedema and have a neuroprotective role in acute ischemic stroke as well as during recovery after stroke. Although mechanisms are still not clear, it appears that NPs enhance angiogenesis, neurogenesis and oligodenrogenesis [3,4]. One of the possible beneficiary effects of NPs during the stroke could be an inhibition of BK pathological function.

\section{Materials and methods}

Aim of our study is to determine beneficial effects of the NPs in stroke development in murine model (middle cerebral artery occlusion - MCAO). The symptoms of the stroke are determined by behavioural studies. The sizes of the lesion and brain oedema are established by $\mu \mathrm{CT}$. Furthermore, we determined the effects of NPs on

\footnotetext{
* Correspondence: asindic@mef.hr

${ }^{2}$ Croatian Institute for Brain Research, School of Medicine, University of Zagreb, Zagreb, 10 000, Croatia

Full list of author information is available at the end of the article
}

the BK signalling pathway in primary culture of neurons and astrocytes using whole cell patch clamp experiments to measure membrane potential and measurements of intracellular $\mathrm{Ca}^{2+}$ concentration.

\section{Results}

In primary isolated astrocytes and neurons, BK binding to type 2 receptor, leads to an increase in intracellular $\mathrm{C}^{2+}$ concentration of astrocytes and neurons, followed by activation of $\mathrm{Ca}^{2+}$-dependent $\mathrm{Cl}^{-}$channel which depolarized the cell membrane. Agonists of guanylate cyclase $\mathrm{A}$, partially guanylate cyclase $\mathrm{C}$ but not guanylate cyclase $\mathrm{B}$ inhibited the effects of $\mathrm{BK}$ at the membrane potential and intracellular $\mathrm{Ca}^{2+}$ concentration via regulators of $\mathrm{G}$ protein signalling. In vivo experiments showed that urodilatin inhibited development of stroke symptoms, the formation of the ischemic lesion and brain oedema.

\section{Conclusion}

The results of this research show the existence of a natural antagonist of the BK receptor type 2 in the mouse brain, and the possible use of NPs in treatment of the stroke.

\section{Acknowledgments}

This study is financed by the National Foundation for Science, Higher Education and Technological Development of the Republic of Croatia and EU-FP7-REGPOT-2012-CT2012-316120 GlowBrain project. Especially we would like to thank Prof. Dr. sc. Ines Drenjančević for providing access to her surgical equipment and setting up the Laser Doppler technique.

\section{Authors' details}

'Department of Histology and Embryology, School of Medicine, University of Zagreb, Zagreb, 10 000, Croatia. ${ }^{2}$ Croatian Institute for Brain Research, School of Medicine, University of Zagreb, Zagreb, 10 000, Croatia. ${ }^{3}$ Department of Anatomy, Histology and Embryology, Faculty of Veterinary Medicine, 
University of Zagreb, Zagreb, 10 000, Croatia. ${ }^{4}$ Department of Anatomy, School of Medicine, University of Zagreb, Zagreb, 10 000, Croatia.

${ }^{5}$ Department of Physiology and Immunology, School of Medicine, University

of Zagreb, Zagreb, 10000, Croatia.

Published: 2 September 2015

\section{References}

1. Rubattu S, Stanzione R, Di Angelantonio E, Zanda B, Evangelista A, Tarasi D, et al: Atrial Natriuretic Peptide Gene Polymorphisms and Risk of Ischemic Stroke in Humans. Stroke 2004, 35(4):814-818.

2. Rubattu S, Ridker PM, Stampfer M, et al: The gene encoding atrial natriuretic peptide and the risk of human stroke. Circulation 1999, 100:1722-1726.

3. Chen XM, Wang NN, Zhang TY, et al: Neuroprotection by Sildenafil: Neuronal Networks Potentiation in Acute Experimental Stroke. CNS Neurosci Ther 2014, 20(1):40-49.

4. Zhang RL, Zhang ZG, Chopp M: Targeting nitric oxide in the subacute restorative treatment of ischemic stroke. Expert Opin Investig Drugs 2013, 22(7):843-851.

doi:10.1186/2050-6511-16-S1-A88

Cite this article as: Dobrivojević et al.: The effect of natriuretic peptides and bradykinin on development of brain oedema after ischemic stroke. BMC Pharmacology and Toxicology 2015 16(Suppl 1):A88.

\section{Submit your next manuscript to BioMed Central} and take full advantage of:

- Convenient online submission

- Thorough peer review

- No space constraints or color figure charges

- Immediate publication on acceptance

- Inclusion in PubMed, CAS, Scopus and Google Scholar

- Research which is freely available for redistribution

Submit your manuscript at www.biomedcentral.com/submit 